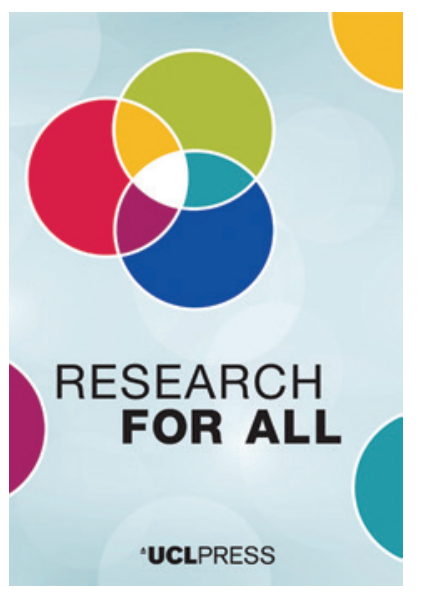

${ }^{ \pm}$UCLPRESS

RESEARCH FOR ALL

The open-access journal for public engagement with research

ISSN 2399-8121 (Online)

Journal homepage:

https://www.uclpress.co.uk/pages/research-for-all

\title{
A learning architecture: Developing a collective design pedagogy in Mumbai with Muktangan School children and the Mariamma Nagar community
}

Nicola Antaki iD

\section{How to cite this article}

Antaki, N. (2021) 'A learning architecture: Developing a collective design pedagogy in Mumbai with Muktangan School children and the Mariamma Nagar community'. Research for All, 5 (1), 101-17. https://doi.org/10.14324/RFA.05.1.09

Submission date: 3 February 2020

Acceptance date: 13 October 2020

Publication date: 16 February 2021

\section{Peer review}

This article has been peer-reviewed through the journal's standard double-blind peer review, where both the reviewers and authors are anonymized during review.

\section{Copyright}

(C) 2021 Antaki. This is an open-access article distributed under the terms of the Creative Commons Attribution Licence (CC BY) 4.0 https://creativecommons.org/licenses/by/4.0/, which permits unrestricted use, distribution and reproduction in any medium, provided the original author and source are credited.

\section{Open access}

Research for All is a peer-reviewed open-access journal. 


\title{
A learning architecture: Developing a collective design pedagogy in Mumbai with Muktangan School children and the Mariamma Nagar community
}

\author{
Nicola Antaki* - University of Sheffield, UK
}

\begin{abstract}
A collective design pedagogy is an idea for a socially engaged learning practice that involves schoolchildren in the production of their city. How can children be involved in (re)designing their environment and work with the wider community, to democratize the city and develop practices of responsible citizenship? The case study is situated in Mumbai, where the changing population, economy and environment have created a need for more child-centred learning activities and pedagogical innovation. In collaboration with education NGO Muktangan School and the neighbourhood Mariamma Nagar, the research sets out a series of pedagogical experiments investigating the city's potential to house sociospatial active citizenship practices by children, school staff and the community, between 2012 and 2017. Four series of workshops included the same class of schoolchildren in observing, assessing and then transforming their environment. Using activities borrowed from architectural practice, they transformed their school and neighbourhood by designing interventions. Critical pedagogical, constructivist and co-design methods included the children in activating what Henri Lefebvre called the right to the city; the development of a collective design practice fuses learning with the environment. Children can become active citizens through design and work with local craft as a political design tool. The children identified well-being as the overarching itinerary for their design projects: they designed responses to problems such as open gutters, mosquitoes, fighting and bad language, lack of green spaces and insufficient waste management. This paper argues that children's role as architects is pedagogical: with facilitation, they can be involved in the production of their current environment, develop their political identity, and foster their ability to communicate ideas. Co-design allows children to develop empathy, think critically and learn how to learn.
\end{abstract}

Keywords: co-design, participation, architecture, citizenship, pedagogy

Key messages

- Children's role as architects is pedagogical: with facilitation, they can be involved in the production of their current environment, develop their political identity, and foster their ability to communicate ideas.

- Practice-led design research allows children to develop empathy, think critically and learn how to learn.

- Children can build local knowledge with local makers and designers to change their environment. 


\section{Introduction}

Alongside the environmental, political, social and economic uncertainties within which we live, and the need to create a sustainable world, there is an increasing disconnect between humans and their environment. This was a key focus for John Dewey's work on learning and pedagogy over a century ago (Dewey, 1916, 1997, 2007). An increasingly urban population means that today children enter a world that is difficult to modify: children's participation in the city is limited. A place-based education can adapt quickly to societal and environmental change as it is rooted in the present day. Today, children need more than ever to be included in the production of the world in order that they learn practices of agency and their right to the city (Lefebvre, 1968): A contemporary pedagogical practice is needed.

This paper sets out the pedagogical experiments that were developed in collaboration with the class of children at Muktangan Love Grove School, to involve them collectively in the design of their environment. Through the co-production of designed interventions for the school and local neighbourhood, how can design (architecture as activity) be used as a method to actively include children in practising their right to the city (architecture as environment) as a kind of sustainable development education? The paper will discuss the methods and incremental participatory nature of the pedagogical attempts, exploring each live project and the relative reciprocity of learning outcomes.

Currently, there is growing awareness and action on the links between environment, education, design and citizenship, globally and in India (Sharma, 2011). For example, supranational policy such as UNESCO Sustainable Development Goals (SDGs) call for practices of Education for Sustainable Development to be integrated into the curriculum, and themes such as 'double-purpose learning' and 'design for change' are increasing in use. Today SDG 4, 'Quality Education', stipulates we must 'ensure inclusive and quality education for all and promote lifelong learning' (UNESCO, 2016). Clause 4.7, 'Education for Sustainable Development', identifies this need as a global necessity. The inclusion of children in design or city planning as learning processes has been intermittently explored throughout the last century (Gandhi, 1946; Lynch, 1977; Gandini, 2012; Freinet, 1969; Ward and Fyson, 1973; Bishop et al., 1992) but has continued to be marginalized as a practice of city making and education; these techniques did not integrate mainstream education for the long term.

The research situates within the context of participatory action research and community-based research with children that has become more popular in recent years, relating to policy demands instigated by the United Nations (UN) Convention on the Rights of the Child (CRC) and the increased recognition of children's rights to participate in decision-making. There is a wealth of literature on children's meaningful participation: Roger A. Hart (1997: 3) writes, it is 'only through direct participation ... [that] children develop a genuine appreciation of democracy and a sense of their own competence and responsibility to participate'. Laura Lundy's (2007) research specifically attends to Article 12 of the CRC, proposing a new model for informing understanding, developing policy and auditing existing practice, with a view to increase the recognition of need for 'pupil voice' in education. Participatory methods such as co-production, which engage children's voices and experiences in research, aim to recognize children's collective expertise and skills, and to underline mechanisms that hold (adult) decisionmakers to account, guarding against control by adult structures and agendas while facilitating children's impact on national decision-making (Kleine et al., 2016; Tisdall, 2017); some also develop environmental agency by engaging with the natural world through critical engagement (Blanchet-Cohen, 2008). 
This project is situated between the fields of pedagogy and design, investigating how architecture (an activity and a setting) can affect children's experience and ability to learn, concentrate and play in the spatial realities of the urban realm. The practiceled design research uses critical pedagogical methods to incrementally develop pedagogical experiments in the context of Mumbai, India. Between 2011 and 2017, I lived, researched and worked in Mumbai, a city in which pluralism and informality can be counted as educational drivers. Multiple series of live projects were held between 2012 and 2017 with the same class of schoolchildren during an incremental, experiential and reflective project to observe, assess and then transform learning environments. The children attended Muktangan School, which comprises seven schools in and around the Worli area. I worked with one of the seven Muktangan schools, namely Love Grove, which caters to many residents of the neighbouring informal settlement Mariamma Nagar. Muktangan School is well-known and holds a positive status within the local community: it is an education non-governmental organization (NGO) that uses constructivist educational approaches to enhance state education, and that caters for low-income urban communities in the global city (Figure 1). It is known as a school that is desirable in terms of education, thanks to its social moral values and ethics, and child-led holistic education.

Using activities borrowed from architectural practice, the children became involved in the transformation of their school and neighbourhood by designing interventions that act generatively and interrogatively. Critical pedagogical methods are central to this research. Paulo Freire's Pedagogy of the Oppressed is based on his lifetime's work to develop a theory of critical pedagogy, founded in a deep knowledge and experience of impoverished and oppressed communities in Brazil. Freire defines many themes that are still particularly relevant today. He proposes that through building a solidarity pedagogy that involves being 'critical of reality' (Freire, 1996: 31) and not perceiving the world as 'closed', we can define and surmount 'limit situations' (Freire, 1996: 80; Viera Pinto, 1960: 284) or the moments where cultural, pedagogical and axiological boundaries meet, with a goal of bringing awareness and consciousness to relieve oppression. He proposes that this would lead to a dialogical revolution (a revolution of conversation), ultimately necessary in its diverse forms for

\section{Figure 1: The school environment (source: author)}

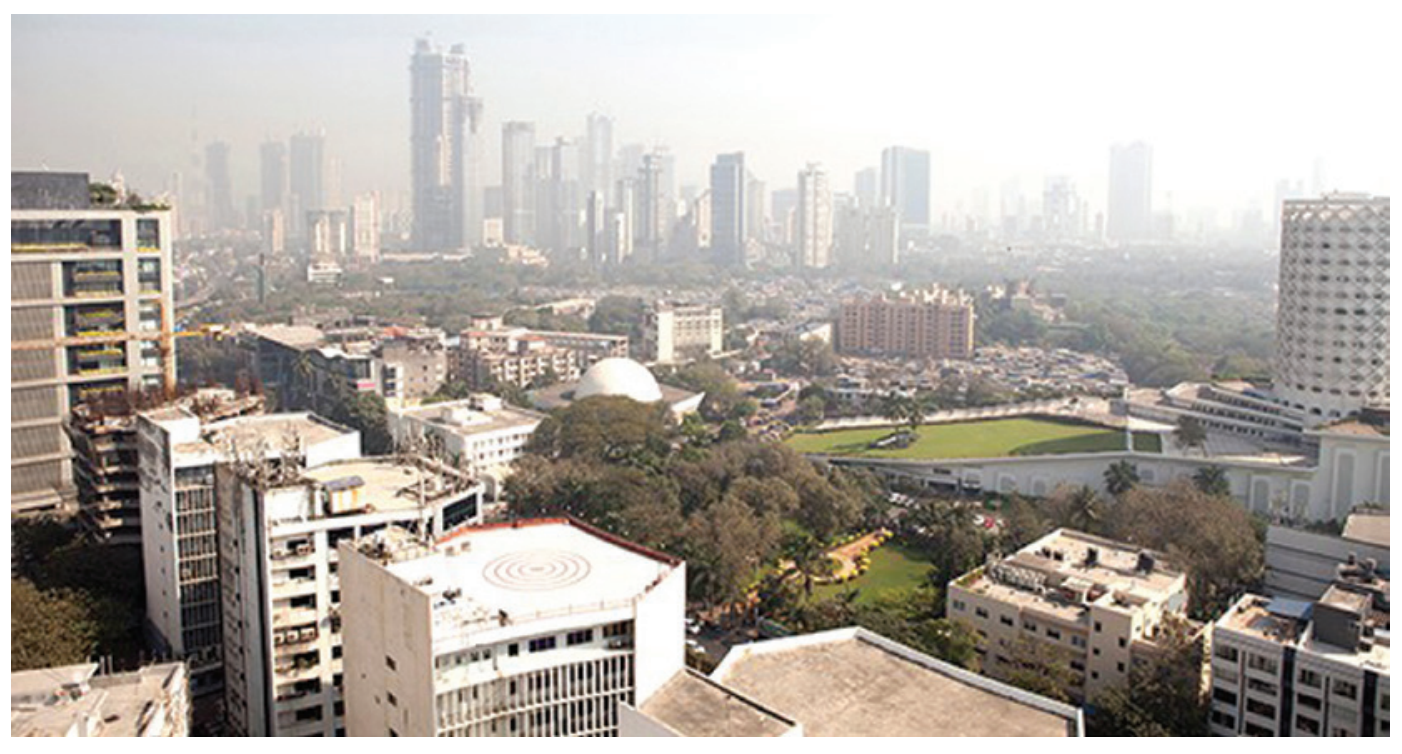


freedom from oppression. Although his critical pedagogy was developed for adults, I argue Freire's critical pedagogy is constructivist in nature, combining the notion of learning to learn with learning to be free, particularly relevant to children's learning. Combining Freire's critical pedagogical praxis and constructivist theory of education, the development of a collective design practice fuses learning with the city: children can become active citizens through design and work with local craft as a political design tool. I found critical pedagogy to be a useful tool for this research in India: as well as using 'conscientization' (Freire, 1996: 56) as a goal for the workshops, I also used critical pedagogy as a means of continuously questioning my own practice, with a constant reassessment of my role as an architect practising an experimental research project, and my role as a teacher at a school in a country that I had known for a relatively short time, in which I am regarded as a foreigner.

This paper argues that children's role as architects is pedagogical: with facilitation, they can be involved in the production of their current environment, develop their political identity, and foster their ability to communicate ideas. Design allows children to develop empathy, think critically and learn how to learn. The paper presents a collective design pedagogy, an idea for a socially engaged learning practice that involves schoolchildren in the production of their city using architectural techniques. It also aims to show that the children were integral to the development of the pedagogical attempts co-creating a reciprocal learning experience for facilitators too.

During the research, a number of ethical protocols were adhered to in order to safeguard the children and the community. The names of the young people mentioned in this paper are pseudonyms in order to protect their privacy, and pictorially they have been anonymized to reduce risk of identification.

\section{Project 1: School Insertions}

The first of the live projects, School Insertions, began in December 2012 involving the Love Grove children in designing interventions for learning situations in their school. School Insertions comprised three sub-projects: Classroom Objects (designs for acoustic attenuation to help with concentration), a Fresh Air Desk (a design for a desk that integrates air-filtering plants) and Edible Garden (a collectively designed and built garden for the school).

Over 12 sessions, the children thought about their learning environment critically, using typical architectural techniques such as listening, observing, ideating, making models, drawing, researching, assessing and presenting (Figure 2). Critical thinking enables people to 'make things happen' rather than 'have things happen to them' (Kumar, 2008: 42), and requires a certain level of empowerment. Freire (1996: 58) explains that the 'banking' form of education is a tool of oppression and a means of controlling a group of people; through not providing the tools for freedom of thought, and critical thought, people cannot think for themselves nor therefore become independent, nor able to take the chances and create the possibilities of making a better life. During School Insertions, through design and design-related discussion, critical thinking was developed visually, spatially and experimentally, using an array of media, attempting to expand the linguistic process to an embodied physical process that involves crafting, drawing and making. We found that critical thinking can be spatial, audible and sensory. But to introduce it at primary school level, activities must be simple to engage young children in questioning the world. 
Figure 2: Classroom workshop (source: author)

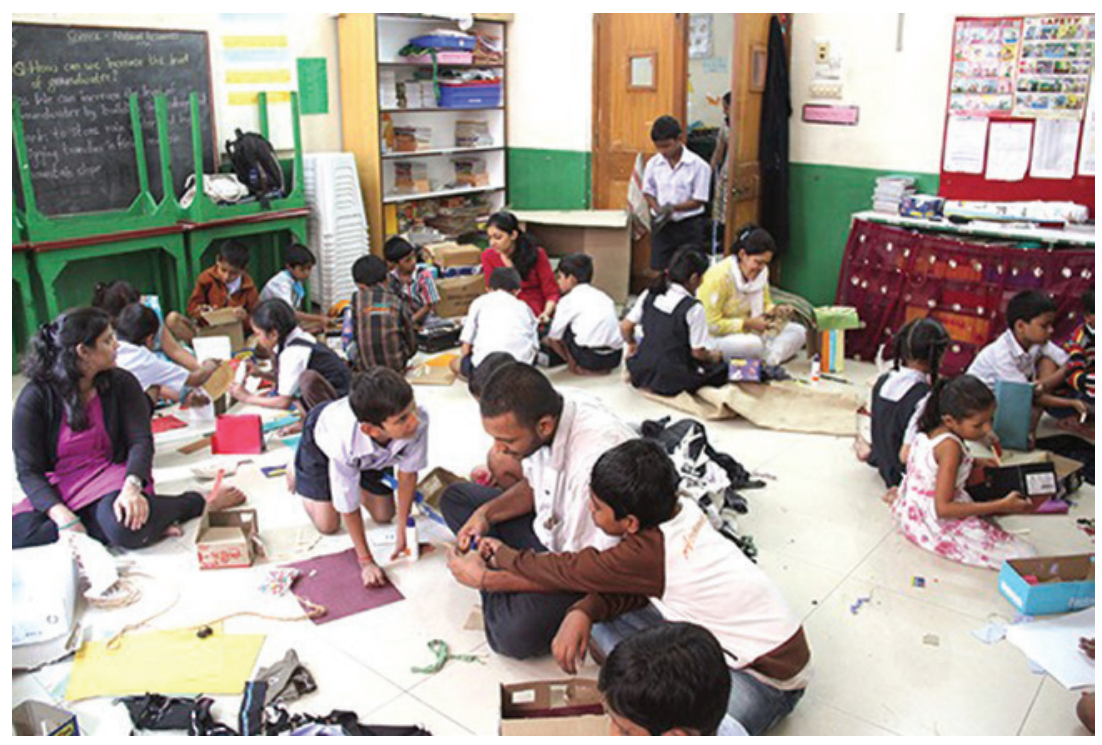

Throughout School Insertions, we learned by doing. By making models, the children began to be critical of the places they dwell, and tried making and re-making the spaces they inhabit, within and without the school grounds. Through this practice, they developed the beginnings of spatial 'conscientization' (Freire, 1996: 58), a building of awareness about how the spaces they inhabit influence their learning experience. They began to identify spatial 'limit situations' (Viera Pinto, 1960) - for instance, where disturbing noises came from and the apertures they came through. However, on the basis of the children's feedback, and upon deeper application of critical pedagogical methods, the sessions had not reached their full potential. As a facilitator, there would be much to learn from this initial project, and pedagogical elements to be identified to develop for future projects.

\section{Informal design itineraries}

According to Freire (1996: 89), the pedagogical itinerary, or chosen route for exploring the thematic universe, must not be presented to the people, nor elaborated from points predetermined by the facilitator. He explains this by writing: 'just as the educator may not elaborate a program to present to the people neither may the investigator elaborate "itineraries" for researching the thematic universe, starting from points which he has predetermined' (ibid.: 90). By 'thematic universe', he means the interaction between the 'concrete representations' (spatial or social) of the 'complex ideas, concepts, hopes, doubts, values and challenges in dialectical interaction with their opposites', and that form themes that 'indicate tasks to be carried out and fulfilled' (ibid.: 82). The 'thematic universe' is the world we live in that includes all the layers and meanings contemporary to the time. It is within the 'thematic universe' that 'limit situations' are to be found.

My initial choice of themes of study relating to healthy environments for learning created a one-way teacher-student relationship, similar to traditional teacher-student relationships. This would have to be reversed, in order to dis-objectify the class: As Hart (1997: 42) writes, 'an important principle to remember is choice'. The openness required in workshop planning to incorporate children's choice of theme meant planning for informality - planning for improvisation and spontaneity - formalizing 
opportunities for informality to inform design processes and decisions. The children could have chosen design itineraries and communication methods, and could have had more time to formulate their own opinions.

\section{Facilitation}

I began running workshops alone, loosely supported by class teachers, whom I would brief before the session. But it quickly became apparent that the sessions would benefit from continuous team facilitation, in order to support children in smaller groups. For the ensuing projects, a team of volunteers would facilitate the projects.

\section{Craft and making}

Our interventions were made using locally found crafts and materials, such as woven cane and bamboo, cotton-filled cushions, and handmade bags, because of their proximity to the school and my experience of working with these materials. It became apparent through my own practice of commissioning craftspeople, making design sketches, negotiating and developing the products with them, that the children would enjoy and benefit from involvement in this part of the design process. As Hart (1997: 44) states, 'to achieve real shared-decision projects, children need to be involved in some degree in the entire process'.

\section{Project 2: Walkabouts}

Held in 2014, Walkabouts involved making a collective map of learning in the children's neighbourhood, Mariamma Nagar, the basti in which many of the Love Grove children live with their families. The neighbourhood is located between two branches of the Love Grove canal in an area of 3.4 hectares (0.034 sq km), opposite the Muktangan Love Grove School building. The informal settlement is centrally located in Greater Mumbai, surrounded by formal urban formations: its neighbours include public and private owners such as the racecourse, the Nehru Science Centre, the municipal Love Grove canals, pumping station and Nehru Planetarium. Quiet, and surrounded on two sides by trees, the settlement is positioned in a complex plural locality that exemplifies its urban complexity by way of its geographical, political and social interrelations with the surrounding city. Mariamma is part of a larger settlement network that is referred to as Jeejamata Nagar, comprising a large proportion of residential dwellings. The settlement is formed of a composition of hutments and buildings. Dense in its physical structure, it is constructed of narrow winding alleys, tiny shops and openings, windows and doors of different shapes and sizes, corners and angled roofs of many materials. Mariamma comprises a mainly Dalit migrant community, of which many are from the northern Indian states and who, despite the difficulties of their home conditions, are making a living. Intertwined with residential dwellings can be found much economic activity that is largely craft and making based. Many karigars, or craftspeople, such as tailors, bag makers and embroiderers, can be found in this settlement.

In small groups, each facilitated by a teacher or volunteer, the children set off to the settlement from school, to map learning in and around the home (Figure 3). Each group of children was given a camera and a number of questions to answer photographically (Figure 4). The children gathered information while walking, which they would later use to create their interpretation of a learning territory; they had no set direction and were led by their curiosity and intuition. Their routes moved through different places and 
Figure 3: A walkabout (source: author)

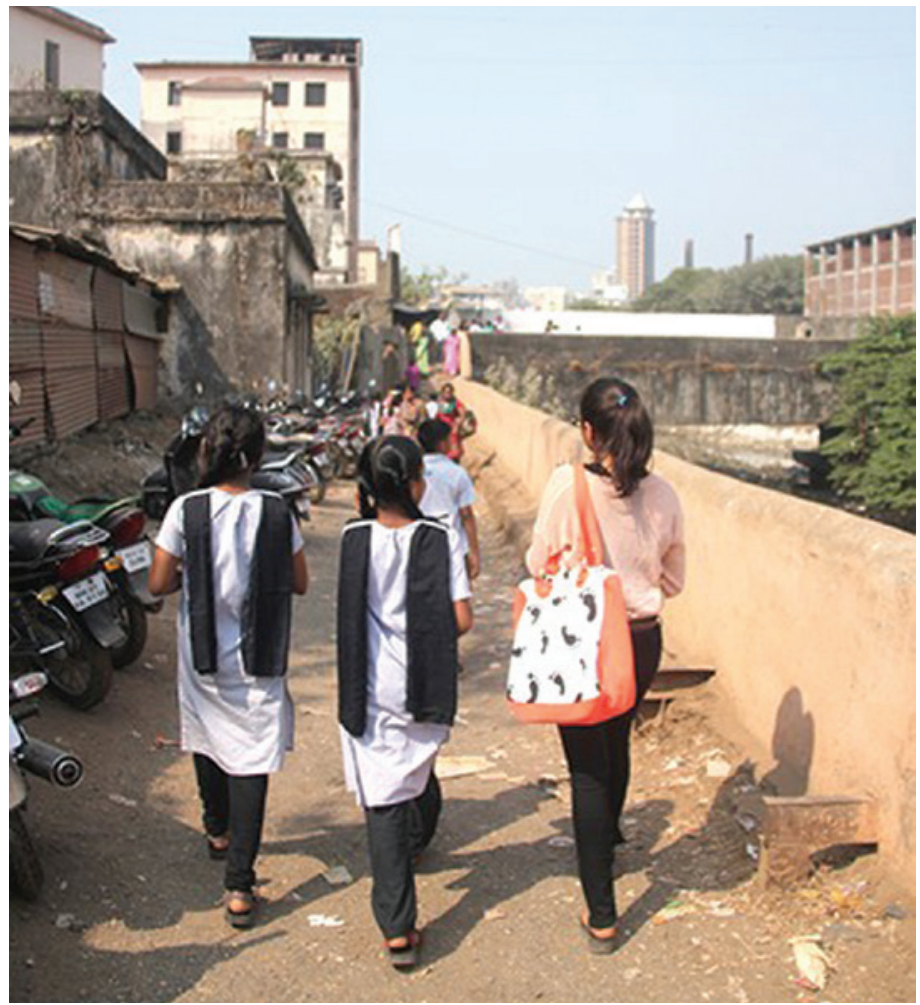

Figure 4: Taking photographs on the walkabout (source: author)

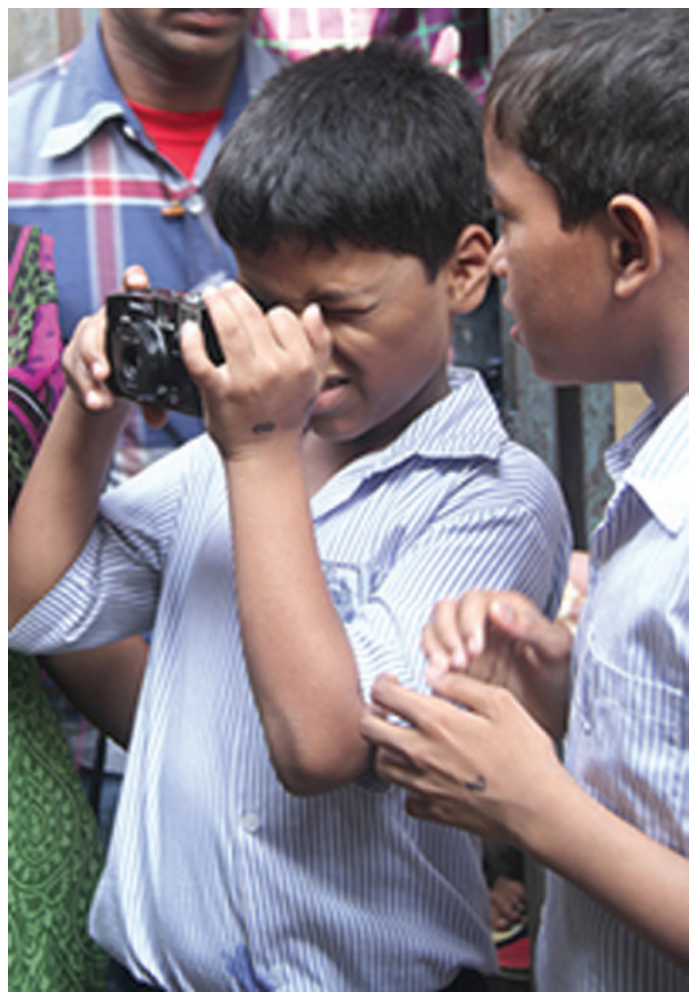


spaces, through social and spatial experiences, sometimes via their homes, capturing objects, people, animals and spaces, positive and negative situations. The camera was a useful democratic creative tool for documentation - each group of four children had one to share between them. Every group member took pictures that responded to the questions set out on clipboards, locating them on a small map.

Back in the classroom, I had set up a template for the map on a large white cotton sheet, locating simple hand-drawn illustrations of neighbourhood landmarks so that the children could orient themselves on the 'page'. They positioned their printed photographs after many conversations and debates, and they added drawings and annotation to the collaged map (Figure 5). Hart (1997: 163) explains that collective drawing has 'the potential of being a central technique in allowing a group to move towards a unified expression of its desires'. Furthermore, he writes that 'It is most likely that the modelling of places also offers the opportunity for children to deal with emotional conflict by symbolising phenomena and dealing with them through manipulation in a way that is not possible in the everyday world' (Hart, 1987: 224). For instance, in the children's map, the canal became filled with drawings of sweet wrappers, pointing to the vast amount of waste the children saw, representing a Freirian limit situation. As anthropologist Tim Ingold (2013: 125) points out, drawing is 'a way of telling'.

\section{Figure 5: Photomap (source: author)}

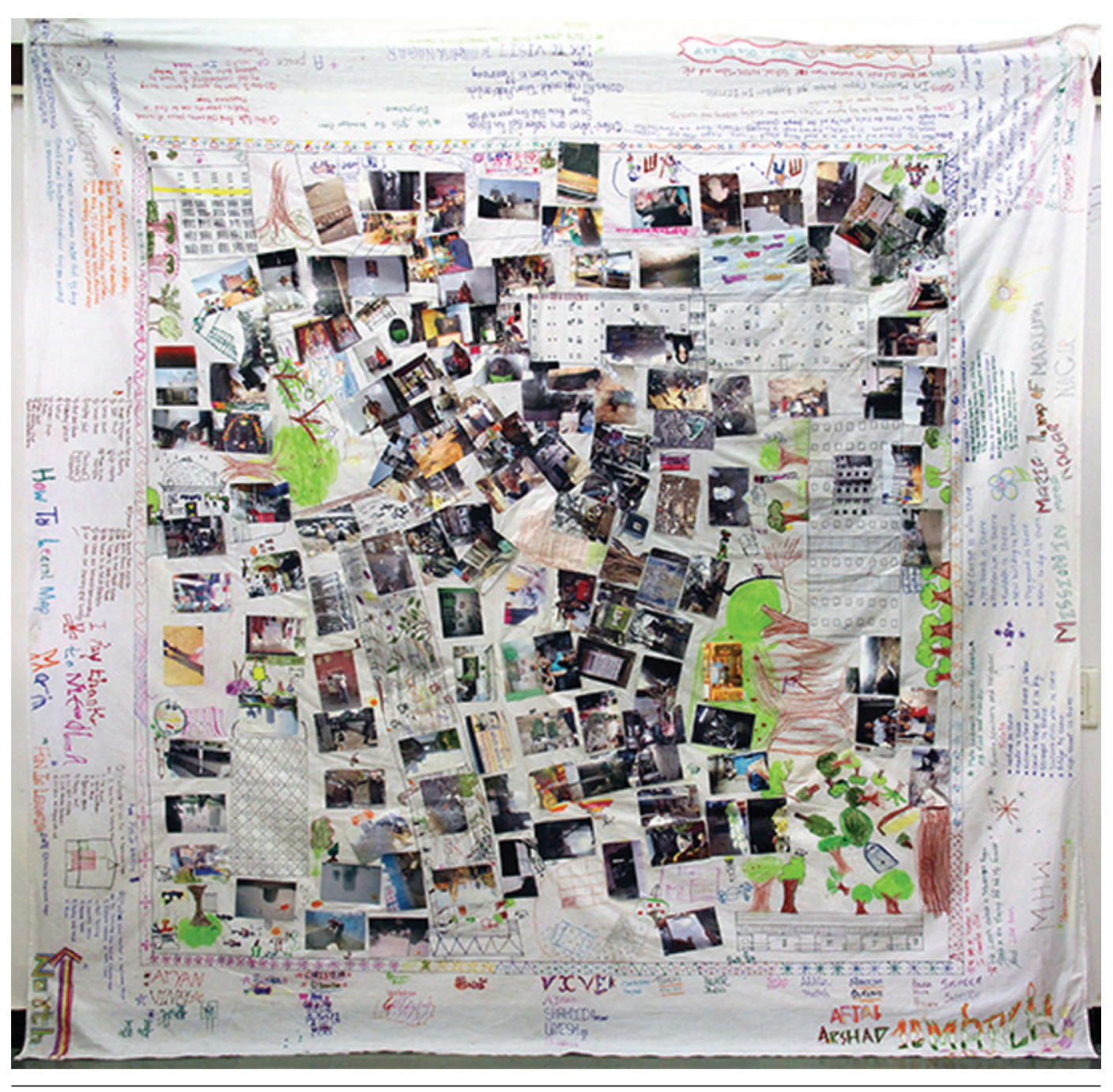


Through the projects School Insertions and Walkabouts, a series of pedagogical techniques were tested. First, using the environment as a teacher, the school grounds both inside and out - and the local neighbourhood as learning resources for children, re-connection between the school and the home can be made. The dialogue between the two environments created a mutual understanding and appreciation in addition to their proximity and many personal ties. The city and the school environments provide a rich palette for contemporary and contiguous learning opportunities through design practices.

Reciprocal and mutual learning between children and facilitators enabled the pedagogical attempts to evolve incrementally. The School Insertions process was problematic: low levels of thematic control by the children meant that I would retrace my steps and further reflect on pedagogical theory in practice. For Walkabouts, I integrated more freedom for the children to direct the project, and actively applied critical pedagogical techniques to both my own and their practice. Practices of spontaneity and improvisation became part of the creative practice as we learned to accept and nurture jugaad, methods of spontaneity that are both social and spatial: social, such as having personal conversations, validations, personal introductions to new networks, and using local languages; and spatial, such as finding local materials (often by exploring and word of mouth), sketching designs with craftspeople, reappropriating found objects, and using what is materially available due to scarce resources. In addition, our work with local craft and making characterized a sustainable socio-spatial technique that enables Freirian 'reciprocity of action' (Freire, 1996: 88).

The 'walkabout' technique provided the ability to perceive and critically document surroundings by walking, looking and photographing. Walkabouts served as an exercise within which to build the 'thematic universe' that Freire specifies cannot be imposed. In addition to these techniques, the Muktangan approach influenced and supported practices of non-competitiveness, socio-emotional learning, and the principle of continuity of experience. The range of children's interests and abilities, and my own interest in developing truly child-led design projects, meant that the project must continue. Walkabouts showed that the children were aware of many important and thought-provoking learning situations in their home environment that could benefit their learning if investigated further. Pedagogical open-endedness became essential, where inquiry led to further inquiry.

Notions of continuity, highlighted by Dewey (1997: 35) as the logical linking together or sequence of experiences, are important factors of learning and growth, and are reflective of life itself. Art and craft or design projects at school usually are not given continuity of activity. The children and staff agreed that the project should continue: the children's initial findings would be the basis for a rich reciprocal learning opportunity, through which we would continue to develop a situated and imaginative design pedagogy.

\section{Project 3: Settlement Interventions}

Following the translation of the children's map into an embroidered tapestry (Figure 6), in 2015 and 2016 the children (ages 11-13) focused on designing interventions for the neighbourhood. In 2015, the children set their own design briefs and designed conceptual responses; in 2016, they designed responses in detail and were involved in the fabrication of their interventions for the settlement.

Settlement Interventions used architectural design techniques such as: documentation of local resources (Figure 7), brief building, dialogue with residents, 
110

Nicola Antaki

Figure 6: Tapestry (source: author)

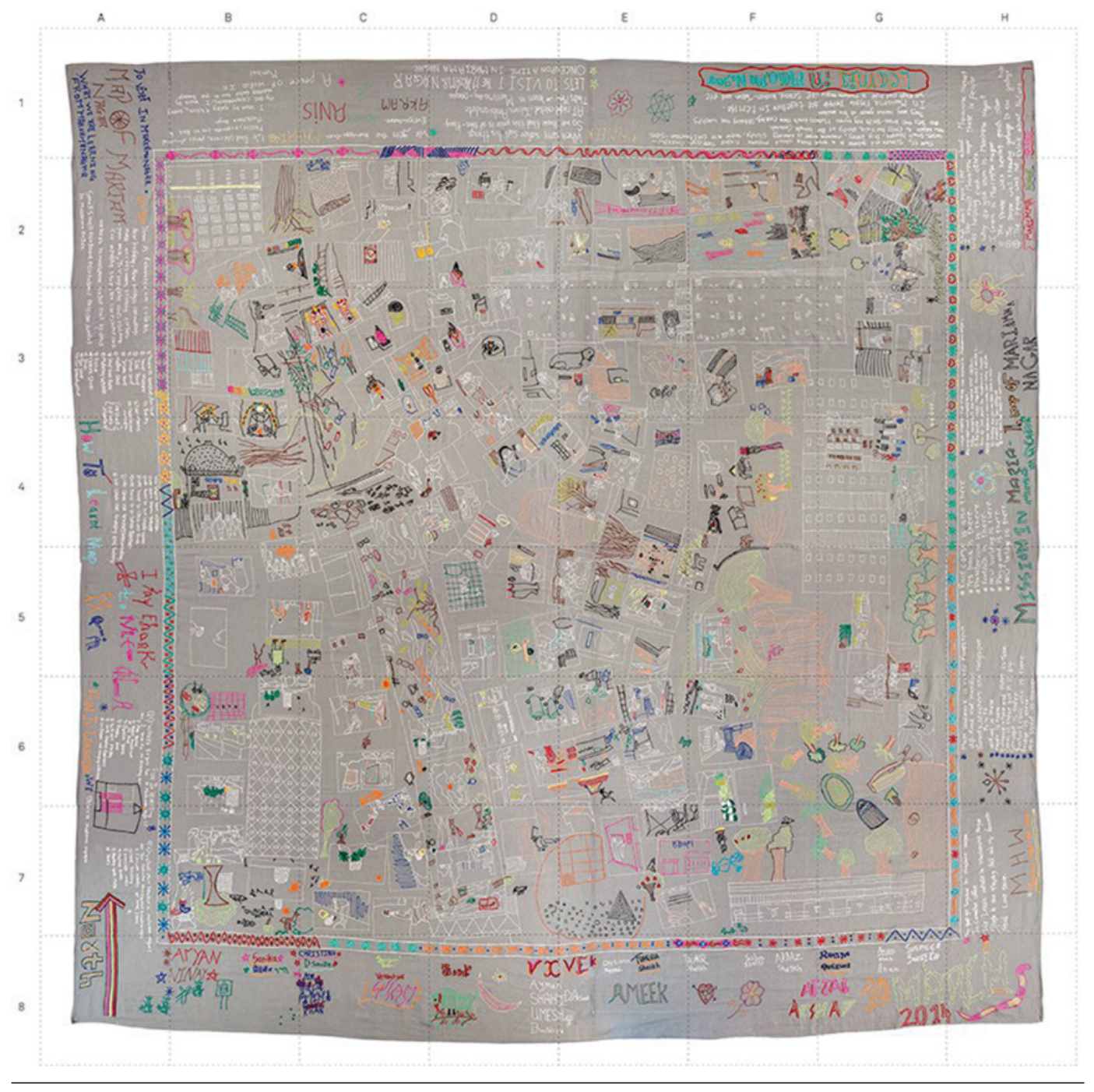

concept design, detailed design, prototype development, collective design, discussion with fabricators, and public presentation. Using drawing as a means of learning, and craft as a local modifier, the neighbourhood provided a place for the children to find and adapt 'limit situations' through what Freire calls conscientizaçao (Freire, 1974: 22).

Figure 7: Craft audit (source: author)

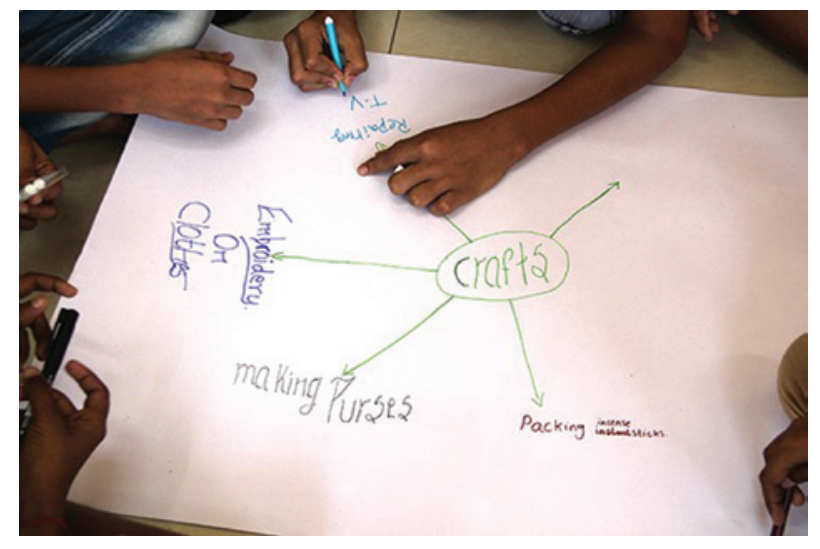

Research for All 5 (1) 2021 
Figure 8: Vote for design themes (source: author)

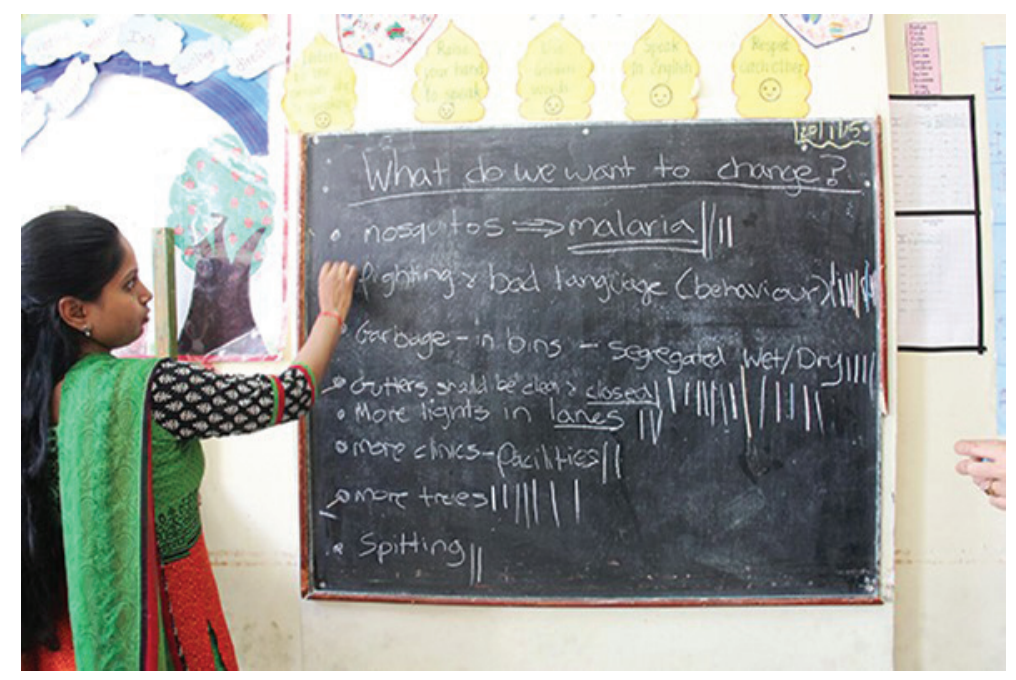

Figure 9: Working with fabricators in the classroom (source: author)

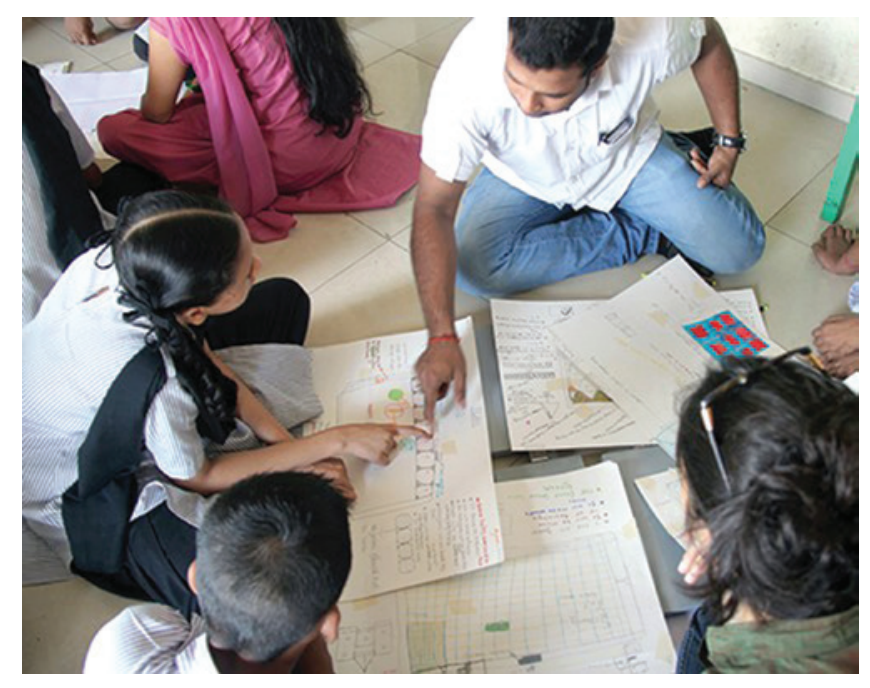

They predominantly identified issues and site conditions relating to health and wellbeing. After a vote to choose five themes (Figure 8), by each marking their choice on the blackboard, they designed responses to problems including open gutters, mosquitoes, fighting and bad language, lack of green spaces and insufficient waste management.

Over the course of 14 sessions, the children designed mosquito nets for neighbourhood doors and windows; a debating table, fine box and banner to tackle fighting and bad language; dry (recycling) and wet (compostable) waste bins to help with waste management; a tin gutter cover for open gutters; and a kitchen herb planter and shopping bag to advocate for more plants in the area. All the interventions were fabricated by local makers. Settlement Interventions showed that children can identify important environmental situations for which they can design imaginative and novel responses, if given an appropriate balance of structure and freedom with the help of facilitators (Figure 9). They can contribute important urban critique and design 
propositions that can directly benefit society. Here, I will identify a number of collective design methods that can be identified as pedagogical.

Documentation of making: The practice of documenting our making activities created space for informal discoveries and became a localizing activity by developing a sense of empowerment and building of local knowledge. Whereas previously I had identified and initiated relationships with craftspeople myself, this time the children were able to develop their own picture of the settlement resources that they would choose from independently. This highlights a move towards greater opportunities for independent participation through choice in reference to Freire's 'thematic universe' as a palette. The 'thematic universe' is the interaction between 'concrete representations' (spatial or social) of the 'complex ideas, concepts, hopes, doubts, values and challenges in dialectical interaction with their opposites', and that form themes that 'indicate tasks to be carried out and fulfilled' (Friere, 1996: 82). I would like to add that making practices also take part in the thematic universe as the concrete socio-economic representations of local creative culture, an important part of the founding strategic basis for the design project. Documenting gave the children opportunities to meet their neighbours, but also acted as an architectural technique of sustainability, using resources close by. Documentation helped emphasize awareness of surroundings.

Brief building: Through walkabouts followed by reflection exercises, the children chose environmental constraints (mosquitoes, insufficient recycling, open gutters, lack of trees, and fighting and bad language) that provided design opportunities. All the constraints they identified focused on the need for improved well-being of the settlement inhabitants. This points to an overarching theme of practice: empathy, an important architectural driver. It is required to imagine how it feels to experience the new space/ place/object, the need to put oneself in another's shoes. Empathy is also a practice of imagination. Gandhi spoke often of empathy as a kind of universal, or global, learning, a move from independent to collective life, in his writings on ahimsa (respect for all living things) (Gandhi, 2010). The idea that learning is dialogical requires an understanding that correspondence, and therefore empathy (or the understanding of the other), is a key educational driver. I propose that brief building helps develop empathy.

Interviewing: The children's position in the projects we devised in Mariamma Nagar had to be balanced: critical but self-situated, relating again to Freire's (1996: 31) notion of solidarity of practice. As Hart (1997: 172) points out, not only is an interview a useful learning experience for the child, but it can also 'dramatically change an adult's opinion of the capacities of a young child'. This technique highlighted the need for rigour of ethical research practices, between community members as well as between facilitators and children, such as understanding informed consent and anonymity. It helped the children identify the variety of opinions among settlement inhabitants, which may differ from their own; this is interconnected with practices of empathy.

Concept design: Sketching initial ideas, the children began to make tangible the imagined ideas, forms or activities they had been formulating through brainstorming diagrams. Some children had immediate ideas for design solutions, such as the debating table, which was then redesigned by other children in the group. Others developed their ideas over longer periods, such as the recycling group, who first explored notions of reusing cloth before moving towards designing a container for waste. 
Control of error: As a design technique, control of error through reflection is a key practice throughout project stages. The activity aimed to demonstrate how important it is to communicate as a designer, and how much information a design drawing may require. Maria Montessori (1949: 370) explains: 'What is necessary therefore in positive science and in practical life must also be included in education from the very beginning: the possibility of a control of error. So, with the teaching and the material must go the control of error.' Regular questioning of what we had done integrated control of error and critical thinking as habitual activities in our practice. In addition, each group routinely presented their critical analysis to the rest of the class.

Detailed design drawings: We practised the architectural technique of designing through drawing in multiple stages, starting with conceptual drawings, then redrawing in a more detailed way. Activities of learning and drawing were reciprocal; drawing was a tool for thought. Eileen Adams (2017: 246) explains that drawing can be of perception, communication, invention and action. Through drawing, the children began to identify how to make spatial meaning, drawing real and imagined pleasure or discomfort, play or people.

Collective design: In architectural practice, there are often a number of options developed for designs, one of which is chosen for further development or amalgamated with another. The practice mirrored this technique; each group of five children chose two or three designs for fabrication. The children demonstrated their ability to socially integrate and work as cohesive groups. Montessori (1949: 349-50) identifies this as 'human nature': she writes that groups of children develop 'as an organism having different characteristics during its natural evolution', comparing life in society to 'weaving and spinning in the manufacture of home-spun cloth which is such an important part of Indian cottage industry'. This connects to Gandhi's (1999: 456) use of the making of khadi in the context of his ideas of ahimsa (respect for all living things), swaraj (self-government), satyagraha (search for truth) and swadeshi (use of local products), and also to his proposition to link the universal to the particular. What Montessori and Gandhi are saying is that if human nature is nurtured (woven or spun) in the right way, it can achieve natural equilibrium. For Gandhi, this would mean acquiring empathy (ahimsa, or non-violence), democracy (swaraj, or home rule) and honesty (satyagraha, or search for truth).

Talking to craftspeople: Communication with fabricators is an important part of design practice, and one of reciprocal learning. The children explained their designs to the craftspeople, who advised on fabrication. The craftspeople's visit to the classroom emphasized the links between imagination and reality created by their drawings, and was a chance for the children to personally discuss their interventions, which gave them confidence and the chance to know 'the why and the wherefore of every process' (Gandhi, 1999: 452). The children had been involved in the entirety of the design process, from brief building through to fabrication.

Prototype presentation: Presentation is integral to design practice: the visual products that have been developed need to be introduced and explained verbally to clients. The children engaged in practices of entrepreneurship: they wanted to 'sell' their products and to convince the community. They used role play - an important learning technique from early ages that uses techniques of imitation to connect imagination 
and empathy - as a technique to practise representing architects and clients; and they told stories to demonstrate the need for their designs.

Evaluation: In order to integrate the project into the curriculum in a way that allowed Muktangan to extract quantitative data to fulfil state requirements, we defined 'rubrics' that would be used to grade the students over the course of the rest of the project, based on what we had observed over the previous two years of research. Setting out the rubrics revealed on paper the interdisciplinary nature and engagement of multiple intelligences of the pedagogical design techniques we devised. During discussions with teachers, we found that the project could be usefully connected with geography, mathematics and biology, as well as civics, art and craft, and work experience. The potential for curriculum integration began to emerge as findings and outcomes became more obvious and measurable.

Multiple disciplines: The idea that design is a tool to learn multiple disciplines is not new: Dewey, Gandhi, Montessori and Tagore all believed this was the case and developed pedagogies to integrate design in some way. The Mahatma Gandhi Institute of Education for Peace and Sustainable Development also advocates in detail how education for sustainable development can integrate multiple subjects, such as mathematics, science, geography and languages lessons, as a multidisciplinary subject that is not additional but integrated into existing subjects. The role of architecture or project-based design in relationship to these subjects is of 'problem-posing' (Freire, 1997: 64): it is a critical pedagogy and an intermediary that emphasizes the need for dialogue and correspondence. Involving children in architecture or design practice allows them to dialogue or correspond with the world.

Reflection: Although we held feedback sessions to reflect on what we had done at the end of each year of research, the detail and effectiveness with which evaluation took place increased throughout this research period of four years. Towards the end of the research, the children were able to identify abstractly what they felt they had learned, how the project had affected them, and how they had developed. Overall, after Settlement Interventions, nearly every child felt they had increased confidence and improved communication skills throughout the project, identifying 'language', 'body language', 'behaviour' and 'presentation skills' as some of the main changes they saw in themselves. Udit says: 'My communication and confidence skills have improved. My big change is how to do teamwork and cooperate with people and how to coordinate with others.' Many of the children also recognized significantly increased 'creativity', 'organization skills', 'thinking level', 'interaction', 'how to change things', 'respect of the environment', 'teamwork' and 'work with society'. Soumya points out that: 'we learned to change first ourselves, and to change others we should help others'. Her comment suggests that the project has helped her to develop solidarity and effective community engagement methods. Vineet articulates: 'Now I know how to work in unity and progress society. I am now confident to present around so many people.' I argue that these changes (and qualities) demonstrate that they have operated as architects.

What is it that design teaches that other subjects do not? My findings suggest that design teaches the intertwined nature of formal and informal practices, of all disciplines, of the need and right to explore and be spontaneous, to listen, to look, to touch, to engage and to act. It is not that the changes the children identified in themselves are design oriented, they are lifelong skills for everyday use, but they are design based, and precisely because they are design based, they can have multi-uses, 
because design is a border pedagogy and a critical pedagogy. It is precisely this imaginative, lateral, transferable and always adaptable capacity of design that makes it a useful tool for learning the right to the city (Lefebvre, 1968). The fact that these themes and qualities are design based is significant. Although the project used design as a pedagogy, the skills the children felt they had developed show that their design thinking and making had benefited universal, multi-use and well-rounded life skills. Design can be a global form of learning, a project-based learning that can contribute to the whole curriculum. Architecture, then, can be counted as a 'global education' using many subjects, or a way of enhancing our understanding and experience of the world by observing, inquiring, learning and proposing. Global skills also relate to practices of global citizenship and universal values, such as tolerance, solidarity, equality, justice, inclusion, cooperation and non-violence. Notably, Aneesha described the project specifically as 'solving problems in a non-violent way', referencing Gandhi's ahimsa.

\section{Conclusion}

This paper has presented a series of workshops that attempted to create a collective design pedagogy, a spatial approach to learning that utilizes architecture (as activity and environment) as an educator. A collective design pedagogy is formed of a toolbox of design workshops, inspired by processes taken from architectural practice and adapted to suit children's abilities. This spatial learning approach brings together children, facilitators and craft communities, in a reciprocal learning practice that can potentially be introduced into mainstream education. In this problem-posing education, all are continuously learners and activists, citizens and change-makers. As a critical pedagogy, it is reciprocal. Using Freirian 'conscientization' to find 'limit situations' in the local 'thematic universe' (environment), while developing 'reciprocity of action', the projects aimed to advance the 'intentionality of consciousness' and the potential for liberation (through citizenship) using learning (Freire, 1996: 56).

A collective design pedagogy is place-based, or, to borrow David Gruenewald's (2008: 149) term, 'a critical pedagogy of place' that can adapt to different localities, communities and situations, to engage with environment, citizenship and craft. It is not a universal, fixed and single methodology. In a collective design pedagogy, children are political protagonists in the design of their environment; they create imaginative projects, meaningful propositions and interventions into the present and the future. These activities also reflect the teachings of Gandhi, Freire and Tagore, whose pedagogies are also to some extent place-based.

A collective design pedagogy is to an extent continuous, reflecting Dewey's (1997: 35) theory that experience is a driver for change translating previous and modifying subsequent experiences longitudinally. Facilitators encourage self-driven responses to environments, document activities, and work as scaffolds to help child development. This approach has the potential to be incremental and open-ended, and must not be static (Freire, 1997: 68): it must mirror and continue to be informed by the informal.

In a collective design pedagogy, informality is a pedagogical ingredient: it leaves opportunity for the use of the imagination of both facilitator and learner. Its rhizomic nature leaves chances for engaging curiosity, empathy, possible futures and narratives; leaving open opportunities for spontaneity, agency, entrepreneurship and innovation.

Engagement processes should not be static methods, and they require continuity with all those involved. Children can be young learners and young architects 
no matter which school they go to or which neighbourhood they live in, if, regardless of their background, they learn to use design as a flexible learning technique. The neighbourhood always provides a classroom, just as the social and spatial environment always provides a site.

The research and proposed approach aims to be usable by schools, organizations and communities to influence mainstream education. The aim to change policy and curriculum builds on UNESCO's Sustainable Development Goal 4.7 and the research of the Mahatma Gandhi Institute of Education for Peace and Sustainable Development. The inclusion of architectural and design practitioners in facilitating this collective design pedagogy could influence social enterprise and the field of spatial professional practices, with a view to making methods of working more inclusive, pedagogical and place-based.

\section{Acknowledgements}

With thanks to Muktangan Love Grove School children, Liz and Sunil Mehta (Muktangan School founders), Chhaya Jadhav (Muktangan Love Grove head teacher), Sarasvati Thakur (Muktangan Love Grove coordinator), Prema Kadam, Veena Pandey and Nigar Shaikh (Muktangan Love Grove teachers), Prathiba Kathe (Muktangan art and craft teacher), Purva Jagtap (Muktangan teacher) and Deelip Satose.

\section{Notes on the contributor}

Nicola Antaki is an architect and postdoctoral researcher (University of Sheffield) specializing in learning, co-design and design for social change. Her doctoral research (UCL Bartlett School of Architecture/DPU, London) investigated architecture as an educator in India. Situated in Mumbai between 2011 and 2019, she combined education and design practices to develop collective design approaches including schoolchildren in (re)designing their environment. Her collective design practice explores involving people in the production of space and activating their right to the city through interdisciplinary means.

\section{References}

Adams, E. (2017) 'Thinking drawing'. The International Journal of Art \& Design Education, 244-52. https://doi.org/10.1111/jade.12153.

Bishop, J., Adams, E. and Kean, J. (1992) 'Children, environment and education: Personal views of urban environmental education in Britain'. Children's Environments, 9, 49-67.

Blanchet-Cohen, N. (2008) 'Taking a stance: Child agency across the dimensions of early adolescents' environmental involvement'. Environmental Education Research, 14 (3), 257-72. https://doi.org/10.1080/13504620802156496.

Dewey, J. (1916) Democracy and Education: An introduction to the philosophy of education. New York: Macmillan.

Dewey, J. (1997) Experience and Education. Originally 1938. New York, Simon and Schuster.

Dewey, J. (2007) The School and Society. Originally 1899. New York, Cosimo Classics.

Freinet, C. (1969) Pour l'Ecole du Peuple. Paris: Maspero.

Freire, P. (1974) 'Conscientisation'. CrossCurrents, 24 (1), 23-31. https://www.jstor.org/ stable/24457877.

Freire, P. (1996) Pedagogy of the Oppressed. 2nd ed. Trans. Ramos, M.B. London: Penguin.

Gandhi, M. (1946) Basic Education. Ahmedabad: Navajivan Publishing House.

Gandhi, M. (1999) The Collected Works of Mahatma Gandhi, 1958-94. New Delhi: Ministry of Information of Broadcasting, Government of India.

Gandhi, M. (2010) Hind Swaraj. Delhi: Rajpal and Sons. 
Gandini, L. (2012) 'History, ideas, and basic principles: An interview with Loris Malaguzzi'. In C. Edwards, L. Gandini and G. Foreman (eds), The Hundred Languages of Children: The Reggio Emilia experience in transformation, 3rd ed. Santa Barbara, CA: Praeger, 27-72.

Gruenewald, David (2008) 'Place-based education: Grounding culturally responsive teaching in geographical diversity'. In D. Gruenewald and G.A. Smith (eds), Place-Based Education in the Global Age. New York and London: Lawrence Erlbaum Associates, Taylor and Francis, 137-53.

Hart, R.A. (1987) 'Children's participation in planning and design'. In C. Weinstein and T.G. David (eds), Spaces for Children: The built environment and child development. New York: Plenum Press, 217-37.

Hart, R.A. (1997) Children's Participation: The theory and practice of involving young citizens in community development and environmental care, UNICEF. London: Earthscan.

Ingold, T. (2013) Making: Anthropology, archaeology, art and architecture. London: Routledge.

Kleine, D., Pearson, G. and Poveda, S. (2016) Participatory Methods: Engaging children's voices and experiences in research. London: Global Kids. Accessed 16 November 2020. www.globalkidsonline.net/participatory-research.

Kumar, A. (2008) 'Development education and dialogical learning in the 21st century'. International Journal of Development Education and Global Learning, 1 (1), 37-48. https://doi.org/10.18546/ IJDEGL.01.1.04.

Lefebvre, H. (1968) Le Droit à la Ville. Paris: Editions Anthropos.

Lundy, L. (2007) "“Voice" is not enough: Conceptualising Article 12 of the United Nations Convention on the Rights of the Child', British Educational Research Journal, 33 (6), Routledge, 927-42. https://doi.org/10.1080/01411920701657033.

Lynch, K. (1977) Growing Up in Cities. Cambridge, MA: MIT Press.

Montessori, M. (1949) The Absorbent Mind. Madras: Theosophical Publishing House.

Sharma, N. (2011) 'Revisiting the concept of dialogue in global citizenship education'. International Journal of Development Education and Global Learning, 3 (2), 5-20.

Tisdall, E.K.M. (2017) 'Conceptualising children and young people's participation: Examining vulnerability, social accountability and co-production'. International Journal of Human Rights, 21 (1), 59-75. https://doi.org/10.1080/13642987.2016.1248125.

UNESCO (2016) Incheon Declaration and Framework for Action for the Implementation of Sustainable Development Goal 4. Accessed 23 November 2020. http://uis.unesco.org/sites/ default/files/documents/education-2030-incheon-framework-for-action-implementation-of-sdg42016-en_2.pdf.

Viera Pinto, A. (1960) Consciencia e Realidade Nacional. Rio de Janeiro: Instituto Superior de Estudos Brasileiros (ISEB).

Ward, C. and Fyson, A. (1973) Streetwork: The exploding school. London: Routledge and Kegan Paul. 